\title{
Corrigendum
}

\section{Carcinoma of an unknown primary: are EGF receptor, Her-2/neu, and c-Kit tyrosine kinases potential targets for therapy?}

C Massard, J-J Voigt, A Laplanche, S Culine, A Lortholary, R Bugat, C Theodore, F Priou, M-C Kaminsky, T Lesimple, X Pivot, B Coudert, J-Y Douillard, Y Merrouche and K Fizazi

British Journal of Cancer (2008) 99, 1959. doi: I0.1038/sj.bjc.6604800 www.bjcancer.com

(C) 2008 Cancer Research UK

Correction to: British Journal of Cancer (2008) 97, 857-861, doi: $10.1038 /$ sj.bjc.6603942

The authors of the above paper, first published in October 2007, would like to add the following acknowledgement to their paper:
We thank Programme Hospitalier de Recherche Clinique (PHRC). 